\title{
Acute necrotizing encephalopathy with SARS-CoV-2 RNA confirmed in cerebrospinal fluid
}

Johan Virhammar, MD, PhD, * Eva Kumlien, MD, PhD,* David Fällmar, MD, PhD, Robert Frithiof, MD, PhD, Sven Jackmann, MD, Mattias K. Sköld, MD, PhD, Mohamed Kadir, MD, Jens Frick, MD, Jonas Lindeberg, MD, Henrik Olivero-Reinius, MD, PhD, Mats Ryttlefors, MD, PhD, Janet L. Cunningham, MD, PhD, Johan Wikström, MD, PhD, Anna Grabowska, MD, Kåre Bondeson, MD, PhD, Jonas Bergquist, MD, PhD, Henrik Zetterberg, MD, PhD, and Elham Rostami, MD, PhD

Neurology ${ }^{\circledR}$ 2020;95:445-449. doi:10.1212/WNL.0000000000010250

\section{Abstract}

Here, we report a case of COVID-19-related acute necrotizing encephalopathy where SARSCoV-2 RNA was found in CSF 19 days after symptom onset after testing negative twice. Although monocytes and protein levels in CSF were only marginally increased, and our patient never experienced a hyperinflammatory state, her neurologic function deteriorated into coma. MRI of the brain showed pathologic signal symmetrically in central thalami, subinsular regions, medial temporal lobes, and brain stem. Extremely high concentrations of the neuronal injury markers neurofilament light and tau, as well as an astrocytic activation marker, glial fibrillary acidic protein, were measured in CSF. Neuronal rescue proteins and other pathways were elevated in the in-depth proteomics analysis. The patient received IV immunoglobulins and plasma exchange. Her neurologic status improved, and she was extubated 4 weeks after symptom onset. This case report highlights the neurotropism of SARS-CoV-2 in selected patients and emphasizes the importance of repeated lumbar punctures and CSF analyses in patients with suspected COVID-19 and neurologic symptoms.

\section{Correspondence}

Dr. Rostami

Elham.rostami@neuro.uu.se

\section{MORE ONLINE}

\section{COVID-19 Resources}

For the latest articles, invited commentaries, and blogs from physicians around the world NPub.org/COVID19

\footnotetext{
*These authors contributed equally to the manuscript.
}

From the Department of Neuroscience (J.V., E.K., S.J.), Neurology, Uppsala University, Uppsala, Sweden; Department of Surgical Sciences (D.F., J.W., A.G.), Radiology, Uppsala University, Uppsala, Sweden; Department of Surgical Sciences (R.F., H.D.P.D.O.-R.), Anaesthesia and Intensive Care, Uppsala University, Uppsala, Sweden; Department of Neuroscience (M.K.S., H.D.P.D.O.-R., E.R.), Neurosurgery, Uppsala University, Uppsala, Sweden; Department of Internal Medicine (M.K., J.L.), Nyköping Hospital, Nyköping, Sweden; Department of Radiology (J.F.), Nyköping Hospital, Nyköping, Sweden; Department of Neuroscience (J.L.C.), Psychiatry, Uppsala University, Uppsala, Sweden; Department of Medical Sciences (K.B.), Uppsala University, Uppsala, Sweden; Department of Chemistry-BMC (J.B.), Analytical Chemistry and Neurochemistry, Uppsala University, Uppsala, Sweden; Department of Psychiatry and Neurochemistry (H.Z.), Institute of Neuroscience \& Physiology, the Sahlgrenska Academy at the University of Gothenburg, Mölndal; and Clinical Neurochemistry Laboratory (H.Z.), Sahlgrenska University Hospital, Mölndal, Sweden. 


\section{Case report}

In early April 2020, a 55-year-old, previously healthy, woman was admitted to the emergency department at a rural hospital due to fever and myalgia. A CT scan of the thorax showed pulmonary ground-glass opacities and consolidations, and PCR analysis of nasopharyngeal swab specimens confirmed the diagnosis of COVID-19. She had been caring for her husband and 90-year-old mother who both had cough and high fever and also tested positive for SARS-CoV-2 RNA.

After returning home the following day, she became lethargic and had difficulty managing the stairs to her bedroom (day 7 after symptom onset, timeline illustrated in the figure). Later that night, she was found unresponsive in bed. At readmission, her temperature was $37.6^{\circ} \mathrm{C}$. She was hemodynamically stable and had no respiratory problems. She was stuporous and had multifocal myoclonus. A CT scan of the brain revealed symmetrical hypodensities in the thalami. A lumbar puncture was performed on day 9 that, in the absence of pleocytosis, did not raise suspicion of CNS infection. PCR tests for herpes simplex virus (HSV) and varicella zoster virus (VZV) were negative. However, signs of blood-brain barrier disruption were noted. On day 11, the patient's neurologic status deteriorated, and she was intubated and transferred to the intensive care unit (ICU). A new CT scan showed low-attenuating areas in the thalami and midbrain, and acute necrotizing encephalitis (ANE) related to her SARS-CoV-2 infection was suspected. Treatment with IV immunoglobulin (IVIG) was initiated in addition to acyclovir.

On day 12 , the patient was transferred to the ICU at a tertiary referral hospital. Her neurologic symptoms had by then worsened, with impaired brain stem reflexes. MRI of the brain showed symmetrical pathologic signal patterns on all sequences, compatible with ANE (figure). In CSF from a second lumbar puncture on day 12 , the cell count was normal, IgG concentration slightly increased, and albumin concentration had normalized. No specific autoantibodies could be detected, and once again, PCR for HSV, VZV, and SARS$\mathrm{CoV}-2$ in CSF was negative.

However, CSF biomarkers for neuronal injury including neurofilament light (NfL) and tau were markedly increased. Glial fibrillary acidic protein (GFAp), a biomarker for astrocytic activation and neuroinflammation, was also highly elevated. In addition, interleukin 6 (IL6) in CSF was somewhat increased. At this time, the systemic inflammatory markers (CRP and WBC) were normal to slightly elevated (figure). Neuronal rescue protein levels were significantly increased in the proteomics analysis of CSF. Other proteins that changed during the disease course included lipid transporters, enzyme cofactors, cell surface receptor ligands, apolipoproteins, and innate immune system complement factors, possibly reflecting the dynamics of the underlying pathology. Proteomics data are available from Dryad, doi.org/10.5061/dryad. xwdbrvlbb.
On day 14, a scant improvement was noted with an increased level of consciousness and normalization of brain stem reflexes. Continuous EEG monitoring showed generalized showed slow waves without epileptiform activity. A second MRI revealed partial regression of the signal changes in the brain stem and medial temporal lobes, while contrast enhancements in central thalami and subinsular regions were more pronounced (figure). Venography showed patent veins, and no hypoperfusion was detected in this patient (image available at Dryad, doi.org/10.5061/dryad.xwdbrv1bb).

Of interest, in the third CSF sampling, rRT-PCR for SARS$\mathrm{CoV}-2$ targeting the $\mathrm{N}$ gene was positive at a cycle threshold value of 34.29. At this low concentration, the finding was not reproducible using a commercial PCR assay (Abbott RealTime SARS-CoV-2; Abbott Molecular, Wiesbaden, Germany). Biomarkers of neuronal injury, NfL and tau, had further increased, whereas GFAp and IL6 had decreased. CSF protein levels were increased, and oligoclonal bands were now detected in CSF.

ANE carries a poor prognosis, and there is no specific therapy because the etiology is unknown. However, because CSF IgG levels were increased, immunotherapy with plasma exchange (PLEX) was started at day 20. We decided against continued treatment with IVIG based on the reported high thromboembolic incidence in patients with COVID-19. The patient received newly collected replacement donor plasma in the hope that it contained SARS-CoV-2 antibodies.

Gradually, the patient's neurologic condition improved, and on day 32 , she could nod, spontaneously, move her legs, and point to a photograph of her children. GFAp had normalized, but $\mathrm{NfL}$ and tau remained strongly increased (figure). She was extubated on day 35 and discharged to rehabilitation.

\section{Discussion}

This case report demonstrates 2 important aspects of SARSCoV-2: first, that the virus may have significant neurotropism, and second, that normal CSF cell counts and initial negative SARS-CoV-2 RNA PCR results in CSF do not exclude CNS engagement. This case also underscores the value of repeated CSF testing when CNS COVID-19 is suspected.

The first report of a patient with COVID-19 and ANE was published in March 2020. ${ }^{1}$ In that case, the presence of virus in CSF was not examined. The case had similar radiologic features as reported here: symmetric thalamic lesions, hemorrhagic components, and involvement of medial temporal lobes and subinsular regions. The latter 2 components are not commonly described features of ANE and could possibly reflect a COVID-19-specific aspect of the pathophysiology. An earlier report by Moriguchi et al. ${ }^{2}$ described a patient with unilateral involvement of the medial temporal lobe where the virus was detected in the CSF. 
Figure Timeline from symptoms to discharge and MRI scans illustrating anatomic location and alterations over time

A
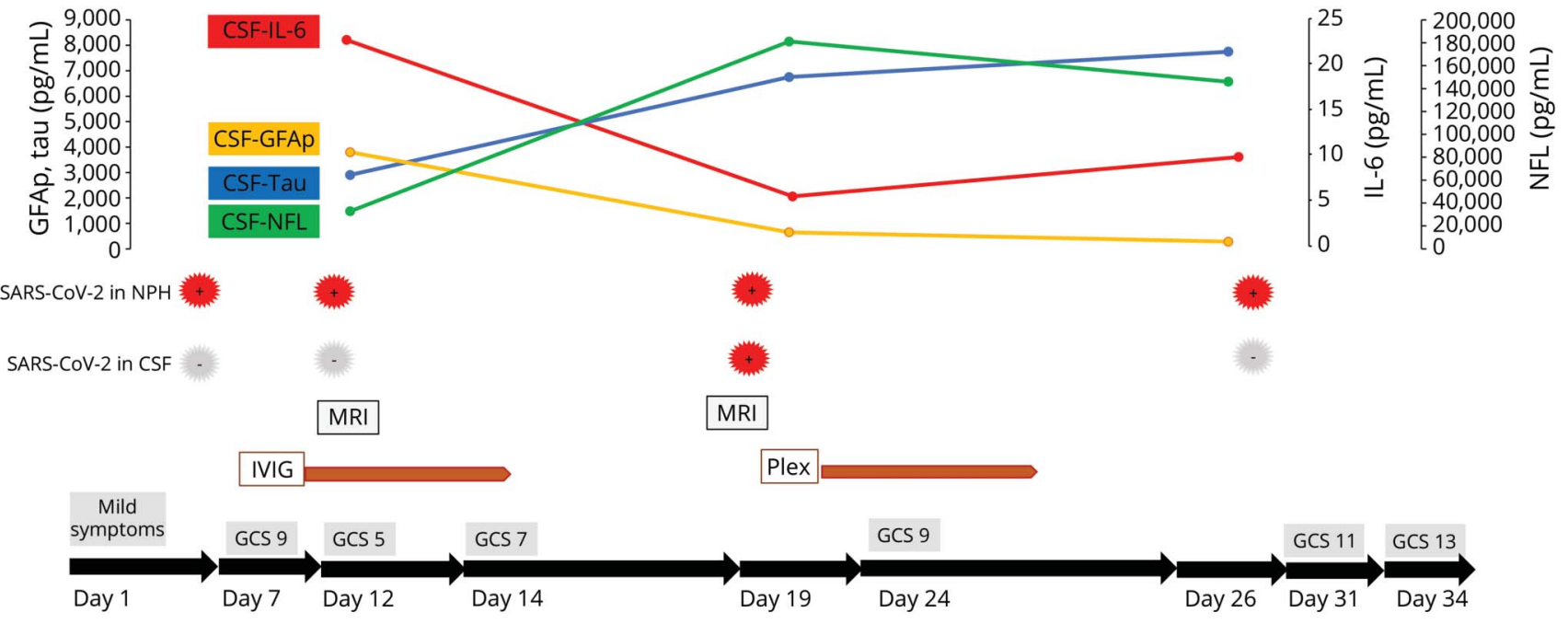

B

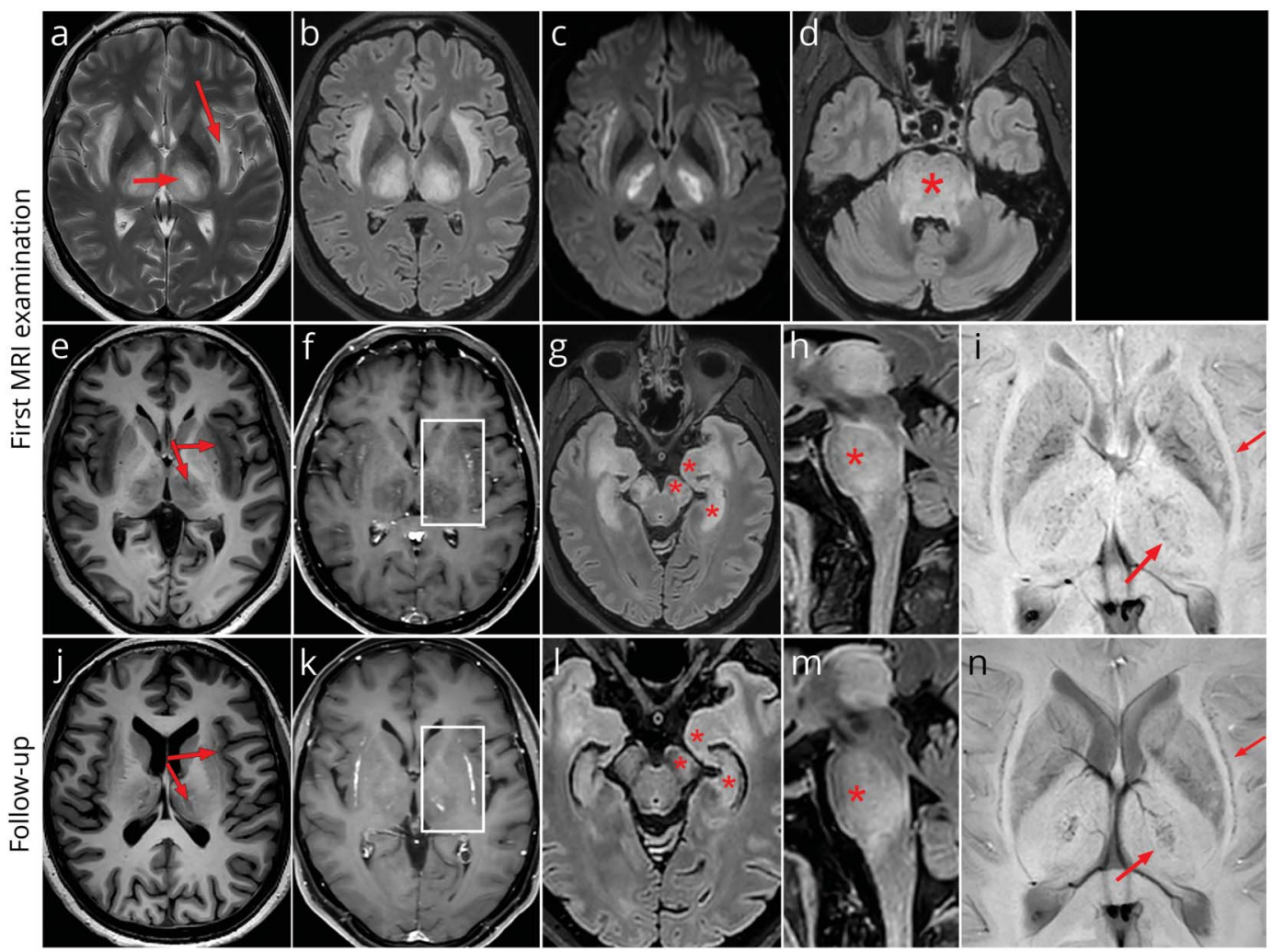

(A) Timeline from symptom debut showing the neurologic status of the patient and the start and duration of the immunotherapies. The graph additionally illustrates the dynamics of inflammatory markers in plasma and CSF. The first and only positive PCR for SARS-CoV-2 in CSF was detected after 3 weeks indicated by red arrows. IVIG, IV immunoglobulin, PLEX, plasma exchange, GCS, Glasgow Coma Scale. (B) The top and middle rows show images from the first MRI scan at day 12, and the bottom row from the follow-up 1 week later. T2 turbo spin echo (B.a) and FLAIR (B.b) show symmetrically increased signal intensity in subinsular regions (surrounding the claustrum) and thalami (red arrow). The same areas had bright signal in trace images from diffusion-weighted images (b 1,000), indicating cytotoxic edema (B.c). Increased signal was also present on FLAIR images in the brain stem (asterisk, B.h) with suggested involvement of trigeminal nerves (without contrast enhancement, B.d). The olfactory tract had normal appearance (not shown). T1-weighted images show distinct signal decrease on the initial scan (B.e), with partial normalization on follow-up and small delineated malacias in the thalami (B.j). There was faint contrast enhancement initially (B.f), more evident on follow-up (boxes; B.k). Initial FLAIR images showed clear symmetrical involvement of medial temporal lobes, hippocampi, and cerebral peduncles (asterisks, B.g), as well as the pons (B.d, B.h). On follow-up, there was substantial decrease of signal changes in hippocampi and mesencephalon (B.I, B.m). Susceptibility-weighted images showed multiple small foci of presumed petechial hemorrhage in central thalami and subinsular regions (red arrows; B.i, B.n). 
ANE is recognized as a distinct entity with a rapid onset of neurologic symptoms, most often secondary to a viral infection such as influenza and herpes viruses. MRI findings include bilateral signal changes and necrosis symmetrically in central thalami and sometimes with hemorrhagic components and/or involvement of the anterior brain stem. Despite its association with viral infection, ANE is not usually considered an inflammatory encephalitis. In fact, the absence of CSF pleocytosis is one of the diagnostic criteria for ANE. ${ }^{3}$ It has been suggested that an intense surge of proinflammatory cytokines causes focal damage to the blood-brain barrier, with edema and necrosis as secondary effects. This cytokine storm or hyperinflammatory state is described in subgroups of patients with viral infections, including COVID-19. In our patient, however, markers for systemic inflammation were only mildly elevated. Immunotherapy in this case led to clinical improvement. This encouraging result, although congruent with a potentially inhibited or halted inflammatory process, should be interpreted with caution.

Neurotropism of coronaviruses and an association with demyelinating lesions have been demonstrated in both human and animal studies. ${ }^{4}$ Recently, SARS-CoV-2 was detected in brain tissue at autopsy, and viral infection of the neurons was confirmed. ${ }^{5}$ A possible route of entry could be the trigeminal and olfactory nerves. ${ }^{6}$ Infiltration through the olfactory system could explain the increased FLAIR signal in the medial temporal lobe. ${ }^{7}$ The signal changes in the brainstem and thalamus may represent a central infiltration through the trigeminal system. The bilateral alterations in the claustrum are very unusual; the findings might be a consequence of neuronal retrograde dissemination as the claustrum has a central position in the limbic system.

High levels of IgG in CSF and oligoclonal bands indicate an ongoing inflammatory process, and demyelination and axonal injury were confirmed by extremely high levels of $\mathrm{NfL}$ and tau.

The virus was detected only after repeated CSF samplings. The single positive test result in CSF coincides with elevated damage markers and could either be a sign of increased virus load/RNA over time, release of virus from damaged nerve cells, or possibly a false-positive test result. The negative test result with the commercial test kit could either be the low sensitivity of the test kit or simply missed by chance. Further studies are needed to confirm this finding and elucidate the route of entry of SARS-CoV-2 into the CNS and the immunologic response in COVID-19-related ANE. The diagnostic and prognostic values of biomarkers for axonal injury and inflammation, MRI, and treatment options with immunotherapy should be key elements in future studies.

\section{Acknowledgment}

The authors thank Niklas Edner at Consultant in Clinical Microbiology at Public Health Agency of Sweden for insightful comments and Ganna Shevchenko for support in the proteomics analysis.

\section{Study funding}

Supported by the Swedish Research Council and Open Medicine Foundation. HZ and ER are Wallenberg Academy Fellows.

\section{Disclosure}

The authors report no disclosures relevant to the manuscript. Go to Neurology.org/N for full disclosures.

\section{Publication history}

Received by Neurology May 14, 2020. Accepted in final form June 19, 2020.

Appendix Authors

\begin{tabular}{lll}
\hline Author & Location & Contribution \\
\hline $\begin{array}{l}\text { Johan } \\
\text { Virhammar, } \\
\text { MD, PhD }\end{array}$ & $\begin{array}{l}\text { Department of } \\
\text { Neuroscience, Neurology, } \\
\text { Uppsala University }\end{array}$ & $\begin{array}{l}\text { Study design, collecting } \\
\text { the data, analysis and } \\
\text { interpretation of the data, } \\
\text { and drafting and revising } \\
\text { the manuscript }\end{array}$ \\
\hline
\end{tabular}

\begin{tabular}{lll}
\hline Eva Kumlien, & $\begin{array}{l}\text { Department of } \\
\text { Neuroscience, Neurology, } \\
\text { Uppsala University }\end{array}$ & $\begin{array}{l}\text { Study design, collecting } \\
\text { the data, analysis and } \\
\text { interpretation of the data, } \\
\text { and drafting and revising } \\
\text { the manuscript }\end{array}$ \\
\hline
\end{tabular}

\begin{tabular}{lll}
\hline David & $\begin{array}{l}\text { Department of Surgical } \\
\text { Sällmar, MD, }\end{array}$ & $\begin{array}{l}\text { Collecting the data, } \\
\text { analysis of data, and } \\
\text { PhD }\end{array}$ \\
Uppsala University & revising the manuscript
\end{tabular}

\begin{tabular}{|c|c|c|}
\hline $\begin{array}{l}\text { Roberth } \\
\text { Frithiof, MD, } \\
\text { PhD }\end{array}$ & $\begin{array}{l}\text { Department of Surgical } \\
\text { Sciences, Anaesthesia and } \\
\text { Intensive Care }\end{array}$ & $\begin{array}{l}\text { Interpretation of data and } \\
\text { revising the manuscript }\end{array}$ \\
\hline $\begin{array}{l}\text { Sven } \\
\text { Jackmann, } \\
\text { MD }\end{array}$ & $\begin{array}{l}\text { Department of } \\
\text { Neuroscience, Neurology, } \\
\text { Uppsala University }\end{array}$ & $\begin{array}{l}\text { Collecting the data and } \\
\text { revising the manuscript }\end{array}$ \\
\hline $\begin{array}{l}\text { Mattias K. } \\
\text { Sköld, MD, } \\
\text { PhD }\end{array}$ & $\begin{array}{l}\text { Department of } \\
\text { Neuroscience, Neurology, } \\
\text { Uppsala University }\end{array}$ & $\begin{array}{l}\text { Collecting the data and } \\
\text { revising the manuscript }\end{array}$ \\
\hline $\begin{array}{l}\text { Mohamed } \\
\text { Kadir, MD }\end{array}$ & $\begin{array}{l}\text { Department of Internal } \\
\text { Medicine, Nyköping } \\
\text { Hospital }\end{array}$ & $\begin{array}{l}\text { Collecting the data and } \\
\text { revising the manuscript }\end{array}$ \\
\hline Jens Frick, MD & $\begin{array}{l}\text { Department of Radiology, } \\
\text { Nyköping Hospital }\end{array}$ & $\begin{array}{l}\text { Collecting the data and } \\
\text { revising the manuscript }\end{array}$ \\
\hline $\begin{array}{l}\text { Jonas } \\
\text { Lindeberg, } \\
\text { MD }\end{array}$ & $\begin{array}{l}\text { Department of Internal } \\
\text { Medicine, Nyköping } \\
\text { Hospital }\end{array}$ & $\begin{array}{l}\text { Collecting the data and } \\
\text { revising the manuscript }\end{array}$ \\
\hline $\begin{array}{l}\text { Henrik } \\
\text { Olivero- } \\
\text { Reinius, MD, } \\
\text { PhD }\end{array}$ & $\begin{array}{l}\text { Department of Surgical } \\
\text { Sciences, Anaesthesia and } \\
\text { Intensive Care, Uppsala } \\
\text { University }\end{array}$ & $\begin{array}{l}\text { Collecting the data and } \\
\text { revising the manuscript }\end{array}$ \\
\hline $\begin{array}{l}\text { Mats } \\
\text { Ryttlefors, } \\
\text { MD, PhD }\end{array}$ & $\begin{array}{l}\text { Department of } \\
\text { Neuroscience, } \\
\text { Neurosurgery, Uppsala } \\
\text { University }\end{array}$ & $\begin{array}{l}\text { Collecting the data and } \\
\text { revising the manuscript }\end{array}$ \\
\hline $\begin{array}{l}\text { Janet L. } \\
\text { Cunningham, } \\
\text { MD, PhD }\end{array}$ & $\begin{array}{l}\text { Department of } \\
\text { Neuroscience, Psychiatry, } \\
\text { Uppsala University }\end{array}$ & $\begin{array}{l}\text { Drafting, interpretation of } \\
\text { the data, and revising the } \\
\text { manuscript }\end{array}$ \\
\hline $\begin{array}{l}\text { Johan } \\
\text { Wikström, } \\
\text { MD, PhD }\end{array}$ & $\begin{array}{l}\text { Department of Surgical } \\
\text { Sciences, Radiology, } \\
\text { Uppsala University }\end{array}$ & $\begin{array}{l}\text { Interpretation of data and } \\
\text { revising the manuscript }\end{array}$ \\
\hline
\end{tabular}


Appendix (continued)

\begin{tabular}{|c|c|c|}
\hline Author & Location & Contribution \\
\hline $\begin{array}{l}\text { Anna } \\
\text { Gabrowska, } \\
\text { MD }\end{array}$ & $\begin{array}{l}\text { Department of Surgical } \\
\text { Sciences, Radiology, } \\
\text { Uppsala University }\end{array}$ & $\begin{array}{l}\text { Interpretation of data and } \\
\text { revising the manuscript }\end{array}$ \\
\hline $\begin{array}{l}\text { Kåre } \\
\text { Bondeson, } \\
\text { MD, PhD }\end{array}$ & $\begin{array}{l}\text { Department of Medical } \\
\text { Sciences, Uppsala } \\
\text { University, }\end{array}$ & $\begin{array}{l}\text { Collecting data, analysis } \\
\text { and interpretation of the } \\
\text { data, and revising the } \\
\text { manuscript }\end{array}$ \\
\hline $\begin{array}{l}\text { Jonas } \\
\text { Bergquist, } \\
\text { MD, PhD }\end{array}$ & $\begin{array}{l}\text { Department of Chemistry } \\
\text { - BMC, Analytical } \\
\text { Chemistry and } \\
\text { Neurochemistry, Uppsala } \\
\text { University }\end{array}$ & $\begin{array}{l}\text { Collecting, analysis and } \\
\text { interpretation of data, and } \\
\text { revising the manuscript }\end{array}$ \\
\hline $\begin{array}{l}\text { Henrik } \\
\text { Zetterberg, } \\
\text { MD, PhD }\end{array}$ & $\begin{array}{l}\text { Department of Psychiatry } \\
\text { and Neurochemistry, } \\
\text { Institute of Neuroscience } \\
\text { \& Physiology, the } \\
\text { Sahlgrenska Academy at } \\
\text { the University of } \\
\text { Gothenburg }\end{array}$ & $\begin{array}{l}\text { Collecting data, analysis, } \\
\text { interpretation of data, and } \\
\text { revising the manuscript }\end{array}$ \\
\hline
\end{tabular}

Appendix (continued)

\begin{tabular}{lll}
\hline Author & Location & Contribution \\
\hline Elham & Department of & $\begin{array}{l}\text { Study design, collecting } \\
\text { Rostami, MD, }\end{array}$ \\
$\begin{array}{l}\text { Neuroscience, } \\
\text { PhD }\end{array}$ & $\begin{array}{l}\text { the data, analysis and } \\
\text { interpretation of the data, } \\
\text { University }\end{array}$ & $\begin{array}{l}\text { and drafting and revising } \\
\text { the manuscript }\end{array}$ \\
\hline
\end{tabular}

\section{References}

1. Poyiadji N, Shahin G, Noujaim D, Stone M, Patel S, Griffith B. COVID-19-associated acute hemorrhagic necrotizing encephalopathy: CT and MRI features. Radiology 2020;296: E119-E120.

2. Moriguchi T, Harii N, Goto J, et al. A first case of meningitis/encephalitis associated with SARS-Coronavirus-2. Int J Infect Dis 2020;94:55-58.

3. Mizuguchi M. Acute necrotizing encephalopathy of childhood: a novel form of acute encephalopathy prevalent in Japan and Taiwan. Brain Dev 1997;19:81-92.

4. Murray RS, Cai GY, Hoel K, Zhang JY, Soike KF, Cabirac GF. Coronavirus infects and causes demyelination in primate central nervous system. Virology 1992;188:274-284.

5. Paniz-Mondolfi A, Bryce C, Grimes Z, et al. Central nervous system involvement by severe acute respiratory syndrome coronavirus -2 (SARS-CoV-2). J Med Virol 2020;92:699-702.

6. Lau KK, Yu WC, Chu CM, Lau ST, Sheng B, Yuen KY. Possible central nervous system infection by SARS coronavirus. Emerg Infect Dis 2004;10:342-344.

7. Perlman S, Jacobsen G, Afifi A. Spread of a neurotropic murine coronavirus into the CNS via the trigeminal and olfactory nerves. Virology 1989;170:556-560.

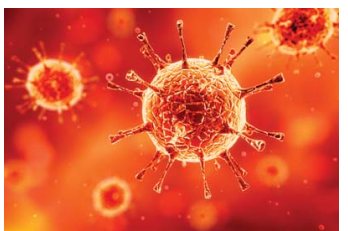

\section{COVID-19 and Neurologic Disease: Call for Papers!}

The editors of Neurology are interested in papers that address the neurological aspects of COVID-19 infection and challenges to the management of patients with chronic neurological conditions who have, or are at risk for, the infection. Relevant papers that pass initial internal review will undergo expedited peer review and online publication. We will consider papers posted in preprint servers.

Submit observational studies and clinical trials as Articles and case series and case reports under the Clinical/Scientific Notes category to https://submit.neurology.org/ today!

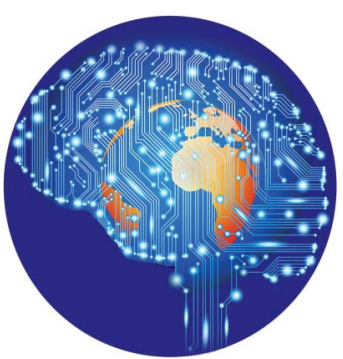

\section{Practice Current: An interactive exchange on controversial topics}

Share your own best practices.

Read commentary with expert opinion.

Explore results on an interactive world map.

NPub.org/NCP/practicecurrent

Neurology ${ }^{\circledR}$ Clinical Practice 


\section{Neurology}

\section{Acute necrotizing encephalopathy with SARS-CoV-2 RNA confirmed in cerebrospinal fluid}

Johan Virhammar, Eva Kumlien, David Fällmar, et al.

Neurology 2020;95;445-449 Published Online before print June 25, 2020

DOI 10.1212/WNL.0000000000010250

This information is current as of June 25, 2020

\section{Updated Information \& Services}

References

Citations

Subspecialty Collections

Permissions \& Licensing

Reprints including high resolution figures, can be found at: http://n.neurology.org/content/95/10/445.full

This article cites 7 articles, 0 of which you can access for free at: http://n.neurology.org/content/95/10/445.full\#ref-list-1

This article has been cited by 4 HighWire-hosted articles: http://n.neurology.org/content/95/10/445.full\#\#otherarticles

This article, along with others on similar topics, appears in the following collection(s):

Encephalitis

http://n.neurology.org/cgi/collection/encephalitis

MRI

http://n.neurology.org/cgi/collection/mri

Viral infections

http://n.neurology.org/cgi/collection/viral_infections

Information about reproducing this article in parts (figures,tables) or in its entirety can be found online at:

http://www.neurology.org/about/about_the_journal\#permissions

Information about ordering reprints can be found online:

http://n.neurology.org/subscribers/advertise

Neurology ${ }^{\circledR}$ is the official journal of the American Academy of Neurology. Published continuously since 1951 , it is now a weekly with 48 issues per year. Copyright Copyright (C) 2020 The Author(s). Published by Wolters Kluwer Health, Inc. on behalf of the American Academy of Neurology.. All rights reserved. Print ISSN: 0028-3878. Online ISSN: 1526-632X.

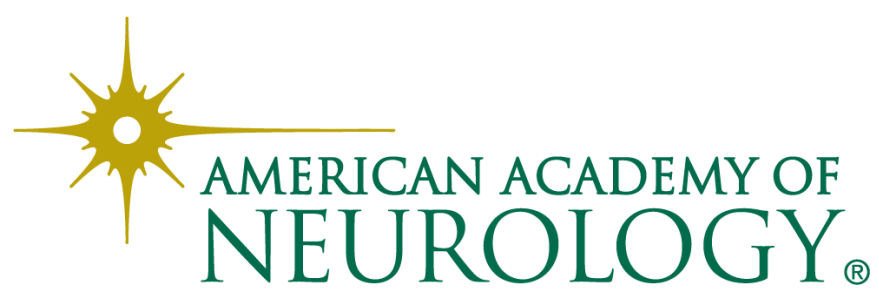

